\title{
RENAL FUNCTIONAL STATUS AND INFLAMMATION ACTIVITY IN PATIENTS WITH CHRONIC KIDNEY DISEASE AND NONALCOHOLIC STEATOHEPATITIS ON THE BACKGROUND OF OBESITY
}

\author{
A.A. Antoniv
}

Higher State Educational Institution of Ukraine "Bukovinian State Medical University", Chernivtsi, Ukraine

Keywords: chronic kidney disease, nonalcoholic steatohepatitis, glomerular filtration rate, oxidative stress, endotoxicosis, lipid distress syndrome, functional state of the endothelium.

Bukovinian Medical Herald. V.22, № 4 (88). P. 3-10.

DOI:

10.24061/2413-0737. XXII.4.88.2018.80

E-mail: antonivalona@ ukr.net
The aim of the study was to find out the probable effect of the comorbid flow of nonalcoholic steatohepatitis on the functional state of the kidneys and the activity of inflammation of the kidneys in patients with chronic kidney disease (pyelonephritis) of the I-III stages, to determine the pathogenetic role of endothelial dysfunction, lipid distress syndrome, endotoxicosis and oxidative stress in the mechanisms of their mutual burden.

Material and methods. 240 patients with chronic kidney disease (chronic bilateral peylonephritis) of the I-III stages were examined, 145 of which had comorbid nonalcoholic steatohepatitis and obesity of the 1st degree (group 1), 95 patients were diagnosed with stages I-III of chronic kidney disease stages without comorbid pathology. Depending on the stage of the chronic kidney disease, both groups were divided as follows: the 1st group - into 3 subgroups: 51 patients with stage 1 of chronic kidney disease, 53 patients with stage 2 of chronic kidney disease, 41 patients with stage 3 of chronic kidney disease. The 2nd group was divided into 3 subgroups: 32 patients with stage 1 of chronic kidney disease, 35 patients with stage 2 of chronic kidney disease, 28 patients with stage 3 of chronic kidney disease. The control group consisted of 30 practically healthy persons.

Results. As a result of the research it was established that nonalcoholic steatohepatitis affects the functional state of the kidneys in patients with stages I-III of chronic kidney disease I-III stages with a possible reduction of nitrogen function, velocity of glomerular filtration, increase in the intensity of hypoalbuminemia, proteinuria, leukocyturia, erythrocyturia, cylinduria, bacteriuria than in isolated course of chronic kidney disease.

Conclusions. For the comorbidity of the chronic kidney disease with nonalcoholic steatohepatitis and a decrease in glomerular filtration rate, an increase in the intensity of oxidative stress, endotoxicosis, lipid distress syndrome, degree of violation of the functional state of the endothelium: increased activity of iNOS, nitrite/nitrate content, endothelin-1, homocysteine, cytokeratin-18, decrease in the activity of arginase, H2S content, which correlate with the intermediate and high power interactions with the index of glomerular filtration rate.

\section{ФУНКЦІОНАЛЬНИЙ СТАН ТА АКТИВНІСТЬ ЗАПАЛЕННЯ НИРОК У ХВОРИХ НА ХРОНІЧНУ ХВОРОБУ НИРОК ТА НЕАЛКОГОЛЬНИЙ СТЕАТОГЕПАТИТ НА ТЛІ ОЖИРІННЯ}

\section{A. А. Антонів}

Мета дослідження - з'ясувати ймовірний вплив коморбідного перебігу неалкогольного стеатогепатиту на функціональний стан нирок та активність запалення нирок у хворих на хронічну хворобу нирок (nієлонефрит) I-III стадії, з'ясувати патогенетичну роль ендотеліальної дисфункції, ліпідного дистрес-синдрому, ендотоксикозу та оксидативного стресу в механізмах їх взаємообтяження. 
Оригінальні дослідження

Буковинський медичний вісник. T.22, № 4 (88).

C. 3-10.

Матеріал і методи. Обстежено 240 хворих на хронічну хворобу нирок (хронічний двобічний пієлонефрит) I-III стадії, 145 з яких мали коморбідний неалкогольний стеатогепатит та ожиріння I cm. (1-ша група), y 95 осіб було встановлено хронічну хворобу нирок I-III стадії без коморбідної патології. Залежно від стадії хронічної хвороби нирок обидві групи розподілилися таким чином: 1-ша група - на три підгрупи: з хронічною хворобою нирок I cm. - 51 пачієнт, із хронічною хворобою нирок II cm. - 53 пачієнти, із хронічною хворобою нирок III cm. - 41 пацієнт. 2-га група розподілилася на три підгрупи: із хронічною хворобою нирок $I \mathrm{~cm}$ - -32 пацієнти, із хронічною хворобою нирок II cm. - 35 паиієнтів, із хронічною хворобою нирок III cm. - 28 пачієнтів. Групу контролю склали 30 практично здорових осіб.

Результати. У результаті досліджень встановлено, щяо неалкогольний стеатогепатит впливає на функиіональний стан нирок у хворих на хронічну хворобу нирок I-III стадій із вірогідним зниженням азотовидільної функції, швидкості клубочкової фільтрації, зростанням інтенсивності гіпоальбумінемії, протеїнурії, лейкоцитурії, еритроцитурії, ииліндрурії, бактеріурії, ніж за ізольованого перебігу хронічної хвороби нирок.

Висновки. За коморбідного перебігу хронічної хвороби нирок та неалкогольного стеатогепатиту із зниженням швидкості клубочкової фільтраиії характерне зростання інтенсивності оксидативного стресу, ендотоксикозу, глибини ліпідного дистрес-синдрому, ступеня порушення функціонального стану ендотелію: зростання активності iNOS, вмісту в крові нітритів/нітратів, ендотеліну-1, гомочистеїну, цитокератину-18, зниження активності аргінази, вмісту в крові H2S, які у взаємозалежності середньої та високої сили корелюють із показником швидкості клубочкової фільтрачї.

\section{Ключевые слова:}

хроническая болезнь

почек, неалкогольный cтеатогепатит, скорость клубочковой фильтрации, оксидативный стресс, эндотоксикоз, липидный дистресс-синдром, функциональное состояние эндотелия.

Буковинский медицинский вестник. T.22, № 4 (88). C. 3-10.

\section{ФУНКЦИОНАЛЬНОЕ СОСТОЯНИЕ И АКТИВНОСТЬ ВОСПОЛЕНИЯ ПОЧЕК У БОЛЬНЫХ ХРОНИЧЕСКОЙ БОЛЕЗНЬЮ ПОЧЕК И НЕАЛКОГОЛЬНЫМ СТЕАТОГЕПАТИТОМ НА ФОНЕ ОЖИРЕНИЯ}

\section{А.А. Антонив}

Цель исследования - выяснить возможное воздействие коморбидности течения неалкогольного стеатогепатита на функииональное состояние почек и активность воспаления почек у больных хронической болезнью почек (пиелонефрит) I-III стадии, вылснить патогенетическую роль эндотелиальной дисфункиии, липидного дистресс-синдрома, эндотоксикоза и оксидативного стресса в механизмах их взаимного отягощения. Материал и методы. Обследовано 240 больных хронической болезнью почек (хронический двусторонний пиелонефрит) I-III стадии, 145 из которых имели коморбидный неалкогольный стеатогепатит и ожирение I cm. (1-ая группа), у 95 человек было установлено хроническую болезнь почек I-ІІІ стадии без коморбидной патологии. В зависимости от стадии хронической болезньи почек обе группь распределились следуюшим образом: 1-ая группа - на три подгруппы: с хронической болезнью почек I cm. - 51 больной, с хронической болезнью почек II cm. - 53 больных, с хронической болезнью почек III cm. - 41 больной. 2-ая группа распределилась на три подгруппь: с хронической болезнью почек I cm. - 32 больных, с хронической болезнью почек II cm. - 35 больных, с хронической болезнью почек III cm. - 28 больных. Группу контроля составили 30 практически здоровых лич. 
Результаты. В результате исследований было установлено, что неалкогольний стеатогепатит влияет на функииональное состояние почек у больных хронической болезнью почек I-III стадий с вероятным снижением азотовьгелительной функции, скорости клубочковой фильтрации, ростом интенсивности гипоальбуминемии, протеинурии, лейкоцитурии, эритроцитурии, ичлиндрурии, бактериурии, чем при изолированном течении хронической болезни почек.

Выводы. При коморбидном течении хронической болезни почек и неалкогольном стеатогепатите со снижением скорости клубочковой фильтрации характерен рост интенсивности оксидативного стресса, эндотоксикоза, глубинь липидного дистресс-синдрома, степени нарушения функиионального состояния эндотелия: рост активности iNOS, содержания в крови нитритов/нитратов, эндотелина-1, гомоцистеина, цчитокератина-18 снижение активности аргиназы, содержания в крови H2S, которые во взаимозависимости средней и высокой силы коррелируют с показателем скорости клубочковой фильтрации.

Relevance of the problem. Comorbidity of chronic kidney disease (CKD) with nonalcoholic steatohepatitis (NASH) in obesity patients has a significant increase in the frequency of this type of comorbidity (15-30\%) [1, $2,3,4,5]$. CKD affects up to $8 \%$ of the adult population of the world, and its prevalence increases significantly in the category of the elderly (up to $38 \%$ ) that suffering from diseases such as obesity, metabolic syndrome, diabetes, arterial hypertension, and smoking $[1,3,4,6,7,8,9]$. In our previous studies, it was found that the clinical course of NASH significantly impairs the comorbidity of CKD, which, in progress, is accompanied by an increasing degree of endogenous intoxication, oxidative and nitrosatitistic stress against the suppression of the antioxidant defense system and the natural system of detoxification, lipid distress syndrome, functional state of the endothelium, disorders of microcirculation, peripheral and organ blood circulation, growing fatty degeneration of hepatocytes (steatosis), cytolytic and cholestatic syndromes, activation of mesenechymal inflammation with the activation of biosynthesis of protein, carbohydrate-protein components of connective tissue extracellular matrix of the liver, kidneys and myocardium with development of their diffuse fibrosis $[9,10]$. The above mechanisms are important links in the pathogenesis of CKD and NASH mutual burden, especially if they occur on the background of obesity, which confirm the results of our studies and the results obtained by other researchers $[2,5,11,12,13]$. At the same time, the degree of these disorders and features of the functional state of the kidneys for the comorbidity of the CKD with NASH have not been established yet.

The aim of the study. To establish the probable effect of the comorbid flow of nonalcoholic steatohepatitis on the functional state of the kidneys and the activity of kidney inflammation in patients with chronic kidney disease (pyelonephritis) of the I-III stages and to determine the pathogenetic role of endothelial dysfunction, lipid distress syndrome, endotoxicosis and oxidative stress in mechanisms of their mutual burden.
Material and methods of research. 240 patients with CKD (chronic bilateral peylonephritis) of the I-III stages were examined, 145 of which had comorbid NASH and obesity of the 1st degree (group 1), 95 patients were diagnosed with CKD I-III stages without comorbid pathology. Depending on the stage of the CKD, both groups were divided as follows: 1st group - into 3 subgroups: 51 patients with 1 st stage CKD, 53 patients with 2 nd stage CKD, 41 patients with 3rd stage CKD. The 2nd group was divided into 3 subgroups: 32 patients with 1st stage CKD, 35 patients with 2nd stage CKD, 28 patients with 3rd stage CKD. The control group consisted of 30 practically healthy persons (PHPs). The average age of patients was $(49.8 \pm 5.8)$ years. The diagnosis of NASH was established in accordance with the unified clinical protocol, approved by the order of the Ministry of Health of Ukraine No. 826 from 06.11.2014, in the presence of criteria for the exclusion of chronic diffuse liver disease of the viral, hereditary, autoimmune or medicinal genesis as causes of cholestatic or cytolytic syndromes, as well as the results of the USG survey. Diagnosis of obesity was established on the basis of calculating the body mass index (BMI) by the formula of Kettle: BMI = body weight $(\mathrm{kg}) /$ height $2(\mathrm{~m})$. On the basis of an increase in BMI of $30-34.9 \mathrm{~kg} / \mathrm{m} 2$, 1st degree it was established, with BMI 35-39.9 kg/m2-2nd degree, BMI above $40 \mathrm{~kg} / \mathrm{m} 2-3 \mathrm{rd}$ degree obesity. The diagnosis of CKD was carried out in accordance with the recommendations of the clinical guidelines of the State Institute "Institute of Nephrology, NAMS of Ukraine" (2012) [2]. The study included patients with CKD I-III stages without a nephrotic syndrome with chronic uncomplicated pyelonephritis in the phase of exacerbation. The glomerular filtration rate (GFR) was investigated by creatinine clearance, calculated using the Cockroft-Gaulta formula, as well as by the universal automatic calculator CKD-EPI [2]. In addition to standard methods of research (blood creatinine, urea, proteinuria, ionograms, urinalysis, urine analysis by the methods of Nechyporenko, Zimnytsky, urine culture with 
the definition of the pathogen, its amount and sensitivity to antibiotics, etc.) we studied the intensity of oxidative stress - by malondialdehyde (MA) content in the blood, intensity of oxidative modification of proteins (OMP) by the content of aldehyde- and ketone dinitrophenylhydrazones neutral (AKDNPH N) and basic (AKDNPH $B$ ). The degree of endogenous intoxication was studied based on the content of the medium molecular peptides (MMP) in the blood and the activity of arginase. The lipid spectrum of blood was studied by the contents of common lipids in blood; total cholesterol (TC), low and high density cholesterol, lipoproteins and triacylglycerol (TG) using a set of reagents of the company Danish LTD (Lviv). The functional state of the endothelium and its regulation were studied in terms of the content of nitrogen monoxide (stable NO metabolites: nitrite/nitrate), hydrogen sulfide (H2S), endothelin-1, homocysteine, cytokeratin-18, induction and endothelial NO synthase activity (iNOS, eNOS) using enzyme-linked immunosorbent assay (ELISA) by using the sets of reagents of the firm "VSM Ukraine" (Ivano-Frankivsk city). The statistical analysis of the results was carried out in accordance with the type of research and the types of numerical data that were obtained. Distribution normality was verified using Liliefors, Shapiro-Uilka tests and the direct visual evaluation of eigenvalues distribution histograms. Quantitative indices having a normal distribution are represented as mean (M) \pm standard deviation (s). For comparisons of data that had a normal distribution pattern, parametric tests were used to estimate the Student's t-criterion, Fisher's F-criterion. In the case of abnormal distribution, the median test, Mann-Whitney Rank U-Score, and Wilcox's T-criterion (in the case of dependent groups) were used for multiple comparison. To measure the relationship between variables, Pearson's correlation analysis using parametric distribution and the Spirman rank correlation coefficient was applied in the case of a distribution of indicators that significantly differed from the normal one. Statistica for Windows version 8.0 (Stat Soft inc., USA), Microsoft Excel 2007 (Microsoft, USA) software packages were used for statistical and graphical analysis of the obtained results.

Research results. Analysis of indicators of the functional state of the kidneys showed that the creatinine content in the blood of the 1 st and the 2 nd group of patients of CKD I st. statistically significantly different. Thus, in patients of group 1, the indicator exceeded the data in the PHPs by 1.5 times $(\mathrm{p}<0,05)$, in group 2 - in 1,3 times $(\mathrm{p}<0,05)$ (table 1). In patients with CKD II st. In group 1 , the creatinine content exceeded the index in PHPs by 1.7 times against 1.5 times in group $2(p<0.05)$. Accordingly, in patients with CKD of the III st. the content of creatinine in patients with group 1 exceeded the data in PHPs by 2.3 times $(\mathrm{p}<0.05)$, in group 2 - by 1.9 times ( $p$ $<0.05$ ), in all cases with the probable difference between groups $(\mathrm{p}<0.05)$ (table 1). Thus, comorbidity with NASH significantly affects the functional parameters of the state of the kidneys, in particular, their nitrogen-containing function. This position is confirmed by the obtained data on the content of urea in the comparative aspect between the groups (table 1). Thus, the urea content in blood in patients with CKD I st. exceeded the indicators in PHPs, respectively, in 1st and 2nd group - in 2,4 and 2,2 times $(\mathrm{p}<0,05)$. In patients with CKD II st. in group 1 the urea content exceeded the index in PHPs by 2.5 times compared with 2.4 times in group $2(\mathrm{p}<0.05)$. Accordingly, in patients with CKD of the III st. the content of urea in patients with group 1 exceeded the data in the PHPs by 2.9 times $(p<0.05)$, in group $2-$ by 2.5 times ( $p$ $<0.05$ ), with the presence of a probable difference between the groups $(\mathrm{p}<0.05)$. An analysis of albumin content in blood also points to a significant difference between the comparison groups. In particular, the index of blood albumin content in patients with CKD I st. was lower than that in PHPs, respectively, in groups 1 and 2 - in 1,3 and 1,2 times $(p<0,05)$, however, the probable difference between the groups was not established $(p>0,05)$. In patients with CKD II st. In group 1, the albumin content was 1.4 times lower than that of PHPs and 1.3 times in group 2 ( $p<0.05)$. Accordingly, in patients with CKD of the III st. albumin content in patients with group 1 was lower than the standard one in 1,5 times $(p<0,05)$, in group 2 - in 1,4 times $(\mathrm{p}<0,05)$, with the probable difference between the groups of patients with comorbidity with NASH and CKD II st. and CKD III st. and for CKD without comorbid diseases $(p<0.05)$. As a result of the established changes, there was a significant decrease in the GFR for creatinine clearance by the Cockroft-Gault formula and calculated by the CKD-EPI (table 1). Thus, the indicator of clearance of creatinine by the CockroftGaulta formula in patients with CKD I st. was lower than that in PHPs only in group 1 patients $(11.8 \%)(\mathrm{p}<0.05)$; in patients of the group 2 , changes were unlikely and no significant difference was found between the groups ( $p>0.05)$. In patients with CKD II st. in group 1 , the creatinine clearance score was lower than the PHPs by $39.2 \%$ versus a decrease of $25.5 \%$ in group $2(p<0.05)$ with a confirmation of statistically significant difference between the groups $(\mathrm{p}<0.05)$. At the same time, in patients with CKD III st. the rate of creatinine clearance in patients in group 1 was lower than the normative at $55.9 \%$ $(\mathrm{p}<0.05)$, in group 2 - by $44.1 \%(\mathrm{p}<0.05)$, with the presence of a probable difference between patients with a combined course NASH and CKD in comparison with patients with CKD without comorbid diseases $(p<0,05)$. Calculation of GFR using CKD-EPI points to a higher accuracy of GFR evaluation, since the index significantly differed between the comparison groups, indicating the probability of our working hypothesis. So, the index of GFR in patients with CKD I st. was lower than that in PHPs in patients of group 1 in 1,5 times $(p<0,05)$, in patients of group $2-$ in 1,3 times $(p<0,05)$ with confirmation of statistically significant difference between groups $(\mathrm{p}<0.05)$. In patients with CKD II st. in group 
1 GFR was 1.9 times lower than the PHPs, compared with a decrease of 1.6 times in group $2(p<0.05)$, with a statistically significant difference between the groups ( $p$ $<0.05)$. At the same time, patients with CKH III st. the rate of GFR in patients in group 1 was lower than the standard in 2.7 times $(p<0,05)$, in group 2 - in 2,2 times $(p<0,05)$, with the presence of a probable difference between patients with a comorbid flow of NASH and CKD II st. and CKD III st. in comparison with patients with isolated CKD of the corresponding stage $(p<0,05)$. Thus, the functional state of the kidneys in patients with CKD and comorbidity with NASH regarding the rates of excretion of nitrogenous slags, albumin loss and integral index - GFR is significantly lowered compared to those in patients with CKD without comorbidity.

In the study of indicators of inflammatory process activity in patients with CKD and comorbidity with $\mathrm{NASH}$ in comparison with the isolated course of CKD, the following data were obtained (table 2). When comparing the number of leukocytes in urine analysis by Nechyporenko method, a significant difference in the indicators was established. So, in patients with CKD I st. in group 1 indicators exceeded the data in the PHPs by 6.9 times (p $<0,05)$, and in 2 groups - by 5,7 times $(\mathrm{p}<0,05)$ (table
2). In patients with CKD II st. in group 1, the number of leukocytes in $1 \mathrm{ml}$ of urine exceeded the normative by 7.9 times against the increase in 6.8 times in group $2(\mathrm{p}<0,05)$. In patients with CKD III st. the content of leukocytes in the urine in patients of group 1 exceeded the normal values by 11.1 times $(\mathrm{p}<0,05)$, in group 2 - by 8,2 times $(\mathrm{p}<0,05)$, in all cases with the probable difference between the groups $(p<0.05)$. When comparing the number of erythrocytes in the analysis of urine by Nechyporenko method we found that in patients with CKD 1 st. in group 1 exceeded the data in the PHPs by 5.7 times $(\mathrm{p}<0,05)$, and in group 2 - by 4,6 times ( $p$ $<0,05$ ) (table 2). In patients with CKD II st. in group 1 , the number of erythrocytes in $1 \mathrm{ml}$ of urine exceeded the normative by 6.9 times against the increase in 5.6 times in group 2 ( $p<0,05)$. In patients with CKD of the III st. the content of red blood cells in patients in group 1 exceeded the normal values by 7.4 times $(p<0,05)$, in group 2 - by 6,0 times $(p<0,05)$, in all cases with a probable difference between the groups $(\mathrm{p}<0.05)$.

Analysis of the daily proteinuria showed a significant difference between the comparison groups (table 2). At patients with CKD I st. in group 1 exceeded the data in PHPs by 7.5 times $(\mathrm{p}<0,05)$, and in group 2

Table 1

Indicators of the functional state of the kidneys in patients with chronic kidney disease and non-alcoholic stethohepatitis, obesity, patients with non-alcoholic stethohepatitis depending on the stage of chronic kidney disease $(\mathrm{M} \pm \mathrm{m})$

\begin{tabular}{|c|c|c|c|c|c|c|c|}
\hline \multirow{3}{*}{$\begin{array}{l}\text { Indicators, } \\
\text { units } \\
\text { measurement }\end{array}$} & \multirow{3}{*}{$\begin{array}{l}\text { PHPs } \\
(n=30)\end{array}$} & \multicolumn{6}{|c|}{ Groups of patients surveyed } \\
\hline & & \multicolumn{3}{|c|}{ Group 1 (NASH, CKD) $(n=145)$} & \multicolumn{3}{|c|}{$\begin{array}{c}\text { Group } 2(\mathrm{CKD}) \\
(\mathrm{n}=95)\end{array}$} \\
\hline & & $\begin{array}{l}\text { CKD I st. } \\
(\mathrm{n}=51)\end{array}$ & $\begin{array}{l}\text { CKD II st., } \\
\quad(n=53)\end{array}$ & $\begin{array}{l}\text { CKD III st. } \\
\quad(n=41)\end{array}$ & $\begin{array}{l}\text { CKD I st., } \\
(n=32)\end{array}$ & $\begin{array}{l}\text { CKD II st., } \\
\quad(n=35)\end{array}$ & $\begin{array}{l}\text { CKD III st. } \\
\quad(n=28)\end{array}$ \\
\hline $\begin{array}{c}\text { Creatinine, } \\
\mu \mathrm{mol} / 1\end{array}$ & $75,0 \pm 2,0$ & $113,2 \pm 2,2^{*}$ & $125,2 \pm 1,4^{*}$ & $169,2 \pm 2,5^{*}$ & $\begin{array}{c}101,2 \pm 2,3 \\
* / * *\end{array}$ & $\begin{array}{c}114,2 \\
\pm 1,9 * / * *\end{array}$ & $\begin{array}{c}143,2 \\
\pm 2,4 * / * *\end{array}$ \\
\hline $\begin{array}{l}\text { Urea, } \\
\mathrm{mmol} / \mathrm{l}\end{array}$ & $3,8 \pm 0,1$ & $9,0 \pm 0,3 *$ & $9,5 \pm 0,1^{*}$ & $10,9 \pm 0,2 *$ & $8,5 \pm 0,4^{*}$ & $9,0 \pm 0,1 * / * *$ & $\begin{array}{c}9,5 \pm \\
0,2 * / * *\end{array}$ \\
\hline Albumin, $\mathrm{g} / \mathrm{l}$ & $40,2 \pm 1,3$ & $32,2 \pm 0,8^{*}$ & $27,2 \pm 0,5^{*}$ & $26,3 \pm 0,4^{*}$ & $33,9 \pm 1,0 *$ & $29,5 \pm 0,3 * / * *$ & $\begin{array}{c}28,0 \pm \\
0,4 * / * *\end{array}$ \\
\hline $\begin{array}{c}\text { Creatinine } \\
\text { Clearance } \\
\mathrm{ml} / \mathrm{min}\end{array}$ & $\begin{array}{c}102,2 \pm \\
2,6\end{array}$ & $90,0 \pm 1,2 *$ & $62,0 \pm 1,1^{*}$ & $45,0 \pm 0,7^{*}$ & $95,0 \pm 1,5^{*}$ & $76,0 \pm 1,0 * / * *$ & $\begin{array}{l}57,0 \pm \\
0,9 * / * *\end{array}$ \\
\hline $\begin{array}{c}\text { GFR CKD- } \\
\text { EPI, ml/ } \\
\min / 1,72 \mathrm{~m} 2\end{array}$ & $101,2 \pm 1,6$ & $68,0 \pm 1,3^{*}$ & $54,0 \pm 1,0^{*}$ & $37,0 \pm 0,6^{*}$ & $77,0 \pm 1,2 * / * *$ & $64,0 \pm 1,2 * / * *$ & $\begin{array}{c}46,0 \pm \\
0,7^{*} / * *\end{array}$ \\
\hline $\begin{array}{l}\text { Notes: } 1 . * \\
\text { comparison }\end{array}$ & the indic & bly comp & $\begin{array}{l}d \text { to the in } \\
\text { f patients } \\
\text { ASH and }\end{array}$ & $\begin{array}{l}\text { in the } \mathrm{PH} \\
\text { he corresp } \\
\text { ity }(\mathrm{p}<0 \text {, }\end{array}$ & $\begin{array}{l}\mathrm{p}<0,05) ; \\
\text { ing stage o }\end{array}$ & $\begin{array}{l}\text { - changes a } \\
D \text { with a co }\end{array}$ & $\begin{array}{l}\text { probably in } \\
\text { rbid flow of }\end{array}$ \\
\hline
\end{tabular}


by 7,0 times $(p<0,05)$. In patients with CKD II st. in group 1 of proteinuria exceeded the index in the PHPs by 8.5 times against the increase in 8.0 times in group 2 (p $<0.05$ ). In patients with CKD of the III st. urine protein loss in group 1 exceeded the norm by 9.5 times $(\mathrm{p}<0,05)$, in group 2 - by 8,5 times $(\mathrm{p}<0,05)$, in all cases with a probable difference between the groups $(p<0.05)$.

The probable results were obtained by us in relation to cylinduria in the comparison of data in patients in group 1 and 2 with CKD I st.: growth of 4,9 and 3,6 times (p $<0,05)$, in CKD II st. - in 6,3 and 3,6 times $(\mathrm{p}<0,05)$, and in CKD III st. - growth in 7,8 and 6,9 times (p $<0,05)$, with the presence in all cases of the probable difference between the groups $(p<0,05)$. The analysis of indicators of bacteriuria also showed the presence of a probable intergroup difference in the analysis of indices in patients with CKD with NASH and without comorbid pathology $(p<0.05)$ (table 2$)$. The correlation analysis shows that there is an average strength and a strong correlation between the GFR indices and the intensity of lipoperoxidation (increase MA content in blood) and the oxidative modification of the proteins (increase in the AKDNPH B content in blood) (table 3), the degree of endotoxicosis (increase of MMP in the blood, decrease in the activity of arginase), growth of fractions of proatherogenic fractions: LDL, cholesterol, TG and lowering of blood HDL - antiatherogenic LP in blood, due to their dysregulation by adipocytokines: hyperleptinemia, hypoadiponectinemia, hypercytocreatinemia ( $p$ $<0.05$ ), indicating the participation of these factors in the reduction of GFR for comorbidity with NASH and the progression of CKD.

It should be noted a significant impact on GFR indicators that contribute to endothelium dysfunction, and its direct biochemical markers. In particular, the significant influence of hydrogen sulfide deficiency, hyperhomocysteinemia, hyperproduction of endothelin-1 and over-expression of iNOS on GFR was established, resulting in hyperproduction and violation of the excretion of metabolites of nitrogen monoxide with activation of nitrosatitistic stress and redistributive impaired renal vascular tone [9], which also affected the decrease in GFR in

Table 2

Characteristics of the intensity of the inflammatory process in patients with chronic kidney disease and non-alcoholic stethohepatitis obesity and chronic kidney disease without comorbidity depending on the stage of the chronic kidney disease $(M \pm m)$

\begin{tabular}{|c|c|c|c|c|c|c|c|}
\hline \multirow{3}{*}{$\begin{array}{l}\text { Indicators, } \\
\text { units } \\
\text { measurement }\end{array}$} & \multirow{3}{*}{$\begin{array}{l}\text { PHPs } \\
(n=30)\end{array}$} & \multicolumn{6}{|c|}{ Groups of patients surveyed } \\
\hline & & \multicolumn{3}{|c|}{ Group 1 (NASH, CKD) $(n=145)$} & \multicolumn{3}{|c|}{$\begin{array}{c}\text { Group } \\
2(\mathrm{CKD}) \\
(\mathrm{n}=95)\end{array}$} \\
\hline & & $\begin{array}{l}\text { CKD I st. } \\
(\mathrm{n}=51)\end{array}$ & $\begin{array}{l}\text { CKD II st., } \\
\quad(n=53)\end{array}$ & $\begin{array}{l}\text { CKD III st. } \\
\quad(n=41)\end{array}$ & $\begin{array}{c}\text { CKD } \\
\text { I st., } \\
(n=32)\end{array}$ & $\begin{array}{l}\text { CKD II st., } \\
\quad(n=35)\end{array}$ & $\begin{array}{l}\text { CKD III st. } \\
\quad(n=28)\end{array}$ \\
\hline $\begin{array}{c}\text { Number of } \\
\text { leukocytes / } \\
1 \mathrm{ml}\end{array}$ & $\begin{array}{c}753,0 \pm \\
23,5\end{array}$ & $\begin{array}{c}5239,0 \pm \\
101,4 *\end{array}$ & $\begin{array}{c}6023,4 \pm \\
138,5^{*}\end{array}$ & $\begin{array}{r}8342,4 \pm \\
246,3 *\end{array}$ & $\begin{array}{c}4316,5 \pm \\
122,1 * / * *\end{array}$ & $\begin{array}{c}5194,2 \pm \\
217,9 * / * *\end{array}$ & $\begin{array}{c}6149,3 \pm \\
269,4^{* / * *}\end{array}$ \\
\hline $\begin{array}{l}\text { Number of } \\
\text { erythrocytes } \\
/ 1 \mathrm{ml}\end{array}$ & $\begin{array}{c}214,3 \pm \\
12,1\end{array}$ & $\begin{array}{c}1223,1 \pm \\
25,1^{*}\end{array}$ & $\begin{array}{c}1497,3 \pm \\
31,7^{*}\end{array}$ & $\begin{array}{c}1588,1 \pm \\
42,0 *\end{array}$ & $\begin{array}{c}989,1 \pm \\
22,8 * / * *\end{array}$ & $\begin{array}{l}1195,0 \pm \\
33,2 * / * *\end{array}$ & $\begin{array}{l}1283,5 \pm \\
38,2 * / * *\end{array}$ \\
\hline $\begin{array}{l}\text { Amount of } \\
\text { protein (g / } \\
\text { day) }\end{array}$ & $\begin{array}{l}0,02 \pm \\
0,001\end{array}$ & $\begin{array}{l}1,5 \pm \\
0,02 *\end{array}$ & $\begin{array}{l}1,7 \pm \\
0,01 *\end{array}$ & $\begin{array}{l}1,9 \pm \\
0,03 *\end{array}$ & $\begin{array}{c}1,4 \pm \\
0,01 * / * *\end{array}$ & $\begin{array}{c}1,6 \pm \\
0,03 * / * *\end{array}$ & $\begin{array}{c}1,7 \pm \\
0,02 * / * *\end{array}$ \\
\hline $\begin{array}{l}\text { Number of } \\
\text { cylinders }\end{array}$ & $\begin{array}{c}2,5 \pm \\
0,2\end{array}$ & $\begin{array}{r}12,2 \pm \\
0,4 *\end{array}$ & $\begin{array}{r}15,7 \pm \\
0,5^{*}\end{array}$ & $\begin{array}{r}19,6 \pm \\
0,6 *\end{array}$ & $\begin{array}{l}9,1 \pm 0,5 \\
* / * *\end{array}$ & $\begin{array}{c}11,0 \pm \\
0,4 * / * *\end{array}$ & $\begin{array}{c}17,3 \pm \\
0,7 * / * *\end{array}$ \\
\hline $\begin{array}{c}\text { Number of } \\
\text { bacteria / } \\
\text { ml }\end{array}$ & $\begin{array}{c}0,56 x \\
102 \pm \\
0,1\end{array}$ & $\begin{array}{c}4,8 \times 105 \pm \\
0,2 *\end{array}$ & $\begin{array}{c}6,9 \times 106 \pm \\
0,3^{*}\end{array}$ & $\begin{array}{c}4,2 \times 107 \pm \\
0,2 *\end{array}$ & $\begin{array}{c}2,2 \times 104 \pm \\
0,3 * / * *\end{array}$ & $\begin{array}{c}4,8 \times 105 \pm \\
1,2 * / * *\end{array}$ & $\begin{array}{c}5,7 \times 106 \pm \\
0,6 * / * *\end{array}$ \\
\hline
\end{tabular}

Notes: $1 . *$ - changes are probably compared to the index in the PHPs $(\mathrm{p}<0,05) ; * * *$ - changes are probably in comparison with the indicator in the group of patients of the corresponding stage of CKD with a comorbid flow of NASH and obesity $(\mathrm{p}<0,05)$. 


\section{\begin{tabular}{rr}
\hline & Table 3
\end{tabular}}

Matrix of correlation relations between CKD-EPI and indicators of lipid homeostasis, endotoxicosis, oxidative stress, functional state of endothelium in obesity and non-alcoholic steatohepatitis patients (r, p)

\begin{tabular}{|c|c|c|c|c|c|c|c|c|}
\hline Indicator & MA & $\begin{array}{c}\text { AKDNPH } \\
\text { B }\end{array}$ & Arginase & MMP & H2S & NO & $\begin{array}{c}\text { Endothe- } \\
\text { lin-1 }\end{array}$ & $\begin{array}{c}\text { Homocys- } \\
\text { teine }\end{array}$ \\
\hline GFR & $-0,68^{*}$ & $-0,63^{*}$ & $0,72 *$ & $-0,69 *$ & $0,75^{*}$ & $-0,63^{*}$ & $-0,45^{*}$ & $-0,64 *$ \\
\hline Indicator & TC & TG & LDL & HDL & Leptin & $\begin{array}{c}\text { Adiponec- } \\
\text { tin }\end{array}$ & iNOS & $\begin{array}{c}\text { Cytokeratin } \\
-18\end{array}$ \\
\hline GFR & $-0,44 *$ & $-0,49 *$ & $-0,61 *$ & $0,67 *$ & $-0,51^{*}$ & $0,43 *$ & $-0,62 *$ & $-0,57^{*}$ \\
\hline
\end{tabular}

Note: * - statistically significant correlation coefficient $(\mathrm{p}<0,05)$.

patients with CKD and NASH $(\mathrm{p}<0,05)$. The obtained data substantially complement the concept of the pathogenesis of the mutual burden of CKD and NASH with obesity [10], contribute to the search for new, previously unknown mechanisms for their progression.

\section{Conclusions}

1. Nonalcoholic steatohepatitis affects the functional state of the kidneys in patients with chronic kidney disease of I-III stages with a possible reduction of nitrogen function, the velocity of glomerular filtration, increase in the intensity of hypoalbuminemia, proteinuria, leukocyturia, erythrocyturia, cylinduria, bacteriuria than in isolated course chronic kidney disease.

2 . For the comorbidity of the chronic kidney disease with nonalcoholic steatohepatitis and a decrease in glomerular filtration rate, an increase in the intensity of oxidative stress, endotoxicosis, lipid distress syndrome, degree of violation of the functional state of the endothelium: increased activity of iNOS, nitrite/nitrate content, endothelin-1, homocysteine, cytokeratin-18, decrease in the activity of arginase, $\mathrm{H} 2 \mathrm{~S}$ content, which correlate with the intermediate and high power interactions with the index of glomerular filtration rate.

The prospect of further research in this direction is to study the factors of regulation of renal functions, the functional state of the endothelium and the development of methods for their correction in patients with a comorbid flow of nonalcoholic steatohepatitis and chronic kidney disease: chronic pyelonephritis.

\section{References}

1. Дідушко ОМ. Вплив ожиріння на функцію нирок у хворих на гіпотиреоз. Клінічна ендокринол. та ендокринна хірургія. 2016; 1 (53): 41-46.

2. Колесник М, Дудар I, Степанова Н. Класифікація хвороб сечової системи для нефрологічної практики: методичні рекомендації. Ін-т нефрології АМН України. Український журнал нефрології та діалізу. 2013; 4 (40): 3-12.

3. Колеснікова ОВ, Дубров КЮ, Крахмалова ЕО. Взаємозв'яз- ки між неалкогольним стеатозом печінки, інсулінорезистентністю та антропометричними показниками у хворих з ознаками метаболічного синдрому. Укр. терапевт. журн. 2010; (3): 81-86.

4. Chang Y, Ryu S, Sung E, et al. Nonalcoholic fatty liver disease predicts chronic kidney disease in nonhypertensive and nondiabetic Korean men. Metabolism. 2008; 57: 569-76.

5. Cheng HT, Huang JW, Chiang CK, et al. Metabolic syndrome and insulin resistance as risk factors for development of chronic kidney disease and rapid decline in renal function in elderly. J. Clin. Endocrinol. Metab. 2012; 97: 1268-76.

6. Dai Y, Zhu J, Meng D, et al. Association of homocysteine level with biopsyproven non-alcoholic fatty liver disease: a meta-analysis. J. Clin. Biochem. Nutr. 2016; 58 (1): 76-83.

7. Franchini S, Savino A, Marcovecchio ML, et al. The effect of obesity and type 1 diabetes on renal function in children and adolescents. Pediatr. Diabetes. 2015; 16: 427-33.

8. Marcuccilli M, Choncho M. NAFLD and Chronic Kidney Disease. Int. J. Mol. Sci. 2016, Apr; 17 (4): 562.

9. Musso G, Cassader M, Cohney S, et al. Fatty Liver and Chronic Kidney Disease: Novel Mechanistic Insights and Therapeutic Opportunities. Diabetes Care. 2016, Oct; 39 (10): 1830-45.

10. Papademetriou M, Athyros VG, Geladari E, et al. The CoExistence of NASH and Chronic Kidney Disease Boosts Cardiovascular Risk: Are there any Common Therapeutic Options? Current Vascular Pharmacology. 2017;15:1-15.

11. Pacifico L, Bonci E, Andreoli GM, et al. The Impact of Nonalcoholic Fatty Liver Disease on Renal Function in Children with Overweight/Obesity. Int. J. Mol. Sci. 2016; 17:1218.

12. Pan LL, Zhang HJ, Huang ZF, et al. Intrahepatic triglyceride content is independently associated with chronic kidney disease in obese adults: A cross-sectional study. Metabolism. 2015; 64: 1077-85.

13. Rong-na L, Xiang-jun Z, Yu-han C, et al. Interaction between hydrogen sulfide and nitric oxide on cardiac protection in rats with metabolic syndrome. Pub. Med. 2011; 33 (1): 25-32.

14. Shufang Z, Chuli P, Feifei Z, Zhi Y. Hydrogen sulfide as 
a potential therapeutic target in fibrosis. Oxid. Med. Cell. Longev. 2015; 2015: Article ID 593407, http://dx.doi. org/10.1155/2015/593407

\section{References}

1. Didushko OM. Vplyv ozhyrinnia na funktsiiu nyrok u khvorykh na hipotyreoz [The effect of obesity on the function of the kidneys in patients with hypothyroidism]. Klinichna endokrynol. ta endokrynna khirurhiia. 2016; 1 (53): 41-46. (in Ukrainian).

2. Kolesnyk M, Dudar I, Stepanova N. Klasyfikatsiia khvorob sechovoi systemy dlia nefrolohichnoi praktyky [Classification of diseases of the urinary system for nephrology practice]. Ukrainskyi zhurnal nefrolohii ta dializu. 2013; 40: 3-12. (in Ukrainian).

3. Kolesnikova OV, Dubrov KIu, Krakhmalova EO. Vzaiemozviazky mizh nealkoholnym steatozom pechinky, insulinorezystentnistiu ta antropometrychnymy pokaznykamy u khvorykh z oznakamy metabolichnoho syndromu [Interrelationships between non-alcoholic steatosis of the liver, insulin resistance and anthropometric indices in patients with signs of metabolic syndrome]. Ukr. terapevt. zhurn. 2010; (3): 81-86. (in Ukrainian).

4. Chang Y, Ryu S, Sung E, et al. Nonalcoholic fatty liver disease predicts chronic kidney disease in nonhypertensive and nondiabetic Korean men. Metabolism. 2008; 57: 569-76.

5. Cheng HT, Huang JW, Chiang CK, et al. Metabolic syndrome and insulin resistance as risk factors for development of chronic kidney disease and rapid decline in renal function in elderly. J. Clin. Endocrinol. Metab. 2012; 97: 1268-76.

6. Dai Y, Zhu J, Meng D, Yu C, Li Y. Association of homocysteine level with biopsy-proven non-alcoholic fatty liver disease: a meta-analysis. J. Clin. Biochem. Nutr. 2016; 58 (1): 76-83.
7. Franchini S, Savino A, Marcovecchio ML, Tumini S, Chiarelli F, Mohn A. The effect of obesity and type 1 diabetes on renal function in children and adolescents. Pediatr. Diabetes. 2015; 16: 427-33.

8. Marcuccilli M, Choncho M. NAFLD and Chronic Kidney Disease. Int. J. Mol. Sci. 2016. Apr; 17 (4): 562.

9. Musso G, Cassader M, Cohney S, et al. Fatty Liver and Chronic Kidney Disease: Novel Mechanistic Insights and Therapeutic Opportunities. Diabetes Care. 2016. Oct; 39 (10): 1830-45.

10. Papademetriou M, Athyros VG, Geladari E, et al. The Co-Existence of NASH and Chronic Kidney Disease Boosts Cardiovascular Risk: Are there any Common Therapeutic Options? Current Vascular Pharmacology. 2017;15:1-15.

11. Pacifico L, Bonci E, Andreoli GM, et al. The Impact of Nonalcoholic Fatty Liver Disease on Renal Function in Children with Overweight/Obesity. Int. J. Mol. Sci. 2016; 17:1218.

12. Pan LL, Zhang HJ, Huang ZF, et al. Intrahepatic triglyceride content is independently associated with chronic kidney disease in obese adults: A cross-sectional study. Metabolism. 2015; 64: 1077-85.

13. Rong-na L, Xiang-jun Z, Yu-han C, et al. Interaction between hydrogen sulfide and nitric oxide on cardiac protection in rats with metabolic syndrome. Pub. Med. 2011; 33 (1): 25-32.

14. Shufang Z, Chuli P, Feifei Z, Zhi Y. Hydrogen sulfide as a potential therapeutic target in fibrosis. Oxid. Med. Cell. Longev. 2015; 2015: Article ID 593407, http://dx.doi. org/10.1155/2015/593407

\section{Відомості про автора:}

Антонів А.А.- кандидат медичних наук, доцент кафедри внутрішньої медицини, клінічної фармакології та професійних хвороб, Вищого державного навчального закладу України «Буковинський державний медичний університет», м. Чернівці, Україна.

Сведения об авторе:

Антонив А.А.- кандидат медицинских наук, доцент кафедры внутренней медицины, клинической фармакологии и профессиональных болезней Высшего государственного учебного заведения Украины «Буковинский государственный медицинский университет», г. Черновцы, Украина.

Information about the author:

Antoniv A.A. - PhD, associate professor of the department of Internal Medicine, Clinical Pharmacology and Occupational Diseases, Higher Educational Institution of Ukraine «Bukovinian State Medical University», Chernivtsi, Ukraine.

Надійила до редакції 17.09.2018 Рецензент - проф. Федів О.I. (C) A.A. Антонів, 2018 